\title{
Tarkwaian Deposits of the Birimian Belt of Houndé: Petrological, Structural and Geochemical Study (Burkina-Faso, West Africa)
}

\author{
Yao Honoré Koffi ${ }^{1}$, Urbain Wenmenga ${ }^{1}$, Sagbrou Chérubin Djro ${ }^{2}$ \\ ${ }^{1}$ Department des Sciences de la Terre, Laboratoire de géoressource, Université Ouagadougou I Pr. Joseph Ky \\ Zerbo, Ouagadougou, Burkina-Faso \\ ${ }^{2}$ Departement des Sciences de la Terre et des Ressources Minières (STRM), Laboratoire de la Géologie du Socle \\ et de Métallogénie, Université Felix Houphouët Boigny, Abidjan, Côte d’Ivoire \\ Email: yaohonorekoffi@gmail.com
}

Received 23 March 2016; accepted 20 May 2016; published 23 May 2016

Copyright (C) 2016 by authors and Scientific Research Publishing Inc.

This work is licensed under the Creative Commons Attribution International License (CC BY). http://creativecommons.org/licenses/by/4.0/

(c) () Op Open Access

\section{Abstract}

The Tarkwaian deposits of the Birimian belt of Houndé are located in the Baoule-Mossi Paleoproterozoic area of the West African Craton. The sedimentary units consist of sandstone heterometric pelitic feldspthic sandstone with locally interbedded breccias, puddings and polygenic conglomerates. Lithic pebbles and macroscopic fragments that are similar to vein type originated quart castings and andesitic-dacitic projections, felsic sub-volcanic rocks evolving from microdioritic to microgranite composition are detected in terrigenous sediments. The volcanic packages form a linear strip composed of basic to intermediate rocks and andesitic to dacitic volcaniclastites. The contacts between these units are not clearly exposed but the different facies between the polygenic conglomerates and sandstones show discordant tectonic contacts with the Tarkwaian and the Birimian. The geochemical nature of these Tarkwaian formations is strongly influenced by the relative decline of the dominant quartz of feldspars and phyllites. The improperly classified and immature feldspathic sandstones show context affinities of island arc probably dictated by Birimian lithic products. Sedimentologically, the cross-bedded stratification and the predominance of sandstone terrigenous lands indicate a deposition in a fluvio-deltaic hydrodynamic setting along intermontane Birimian rift. The similarities between these Tarkwaian formations and the typical Tarkwaian of the Tarkwa basin in Ghana are probably limited to petrographic and not stratigraphic aspects, which lead to likening them to flyschoïd or molassic tardi Birimian deposits. 
Keywords

Tarkwaian, Birimian, Sandstone, Polygenic Conglomerat, Molassic, Fluvio-Deltaic

\section{Introduction}

Located in the southwest of Burkina Faso, the Birimian belt of Houndé is a linear volcano-sedimentary belt and truncated in the northern part. It belongs to the Baoule-Mossi Paleoproterozoic area in the Leo shield in the West African Craton, mainly dominated by the Birimian volcano-sedimentary sequences. The lithostratigraphy of the Birimian has long been subject to much controversy. Thus, according to the works of Junner [1], in the Birim valley where it was definite in Ghana, the author divides the Birimian into a lower sedimentary series and an upper volcanic series [1]. This stratigraphy was extended to the different belts of the Baoule-Mossi area [2].

But in light of recent data, it was clear that each greenstone belt displayed a clean lithostratigraphy, probably nuanced within the West African Craton. Defined as an essentially coarse terrigenous sedimentary series, the Tarkwaian is formed in intermontane basins [3] relatively late in the building of the Birimian crust. The Ghana Tarkwaian is said to be unconformably deposited on the Birimian considered as younger [4] but part and parcel of the Birimian system [5].

According to the first authors who dedicated their work to the Tarkwaian in Ghana [1] [6] [7], from a lithostratigraphic perspective, this purely sedimentary system begins with the Kawere group and is basically composed of polygenic conglomerates and sandstone, whose thickness varies between $250 \mathrm{~m}$ and $700 \mathrm{~m}$. It is covered by forming Banket consisting of alternating conglomerates with sandstone bedding. These Tarkwaian formations represent $600 \mathrm{~m}$ thickness, a cross-bedded stratification marked by fine levels of magnetite. The conglomerates are mainly composed of quartz pebbles to the extent of over $90 \%$ and basic Birimian rocks [8]. They are home to the alluvial gold deposit of the Tarkwa basin. The Tarkwa series consisted of $400 \mathrm{~m}$ thick phyllites overlain by the quartzite of the Huni group, interspersed with a few levels of phyllites over more than $1300 \mathrm{~m}$ at the sommit. The discovery of gold deposits in the Ghana Tarkwaian series sparked a craze for boosting precious metals in similar formations in neighboring countries including Côte d'Ivoire, Mali, Burkina-Faso and Niger [9] [10]. The detrital sedimentary units described in these regions have been attributed to the Tarkwaian system even when the stratigraphic correlations with the Ghana Tarkwaian are not known. In fact, except for the conglomeratic levels reported in many areas and regionally in other sedimentary formations or groups, often probably stratigraphic gaps compared to the typical Tarkwaian [11]-[15] attributed the terrigenous sedimentary formations of the Houndé belt to the Tarkwaian system.

The subject matter of this study is based on petrographic, sedimentological and geochemical analysis in order to understand the source of Tarkwaian sediments and their geodynamic setting of deposition around the Birimian belt of Houndé.

\section{Geological Setting}

The Leo shield is divided into two areas: the Archean Keneman-Man area and Paleoproterozoic Baoule-Mossi area expressed by Eburnean orogenic cycle (2200 - $2000 \mathrm{Ma}$ ) to which the Birimian formations are related [15]. The exclusively detrital depositions called Tarkwaian derive from the demolition of the Birimian formations. The Birimian and Tarkwaian are generally affected by a regional metamorphism whose intensity does not exceed the greenschist facies. Studies on the amphibole/plagioclase assembling suggest maximum temperature and pressure conditions of around $500^{\circ} \mathrm{C}-650^{\circ} \mathrm{C}, 5-6 \mathrm{kbar}$ [16] and $520^{\circ} \mathrm{C}, 5.4 \mathrm{kbar}$ [17]. On the structural plan, [18]-[20] showed that the structural nature of the Eburnean is polyphase by defining three (3) phases of deformations (D1, D2, D3) in which they try to put the Tarkwaian system in the last two phases.

\section{Regional Geology}

Burkina-Faso covers the eastern part of the Leo shield. Based on the reports of [15] the geology of Burkina Faso is composed of three lithotectonic areas Figure 1. The Paleoproterozoic area commonly called "Birimian" in the central part, the Neoproterozoic to Paleozoic sedimentary cover and panafrican chains of the Buem Attacora in the 


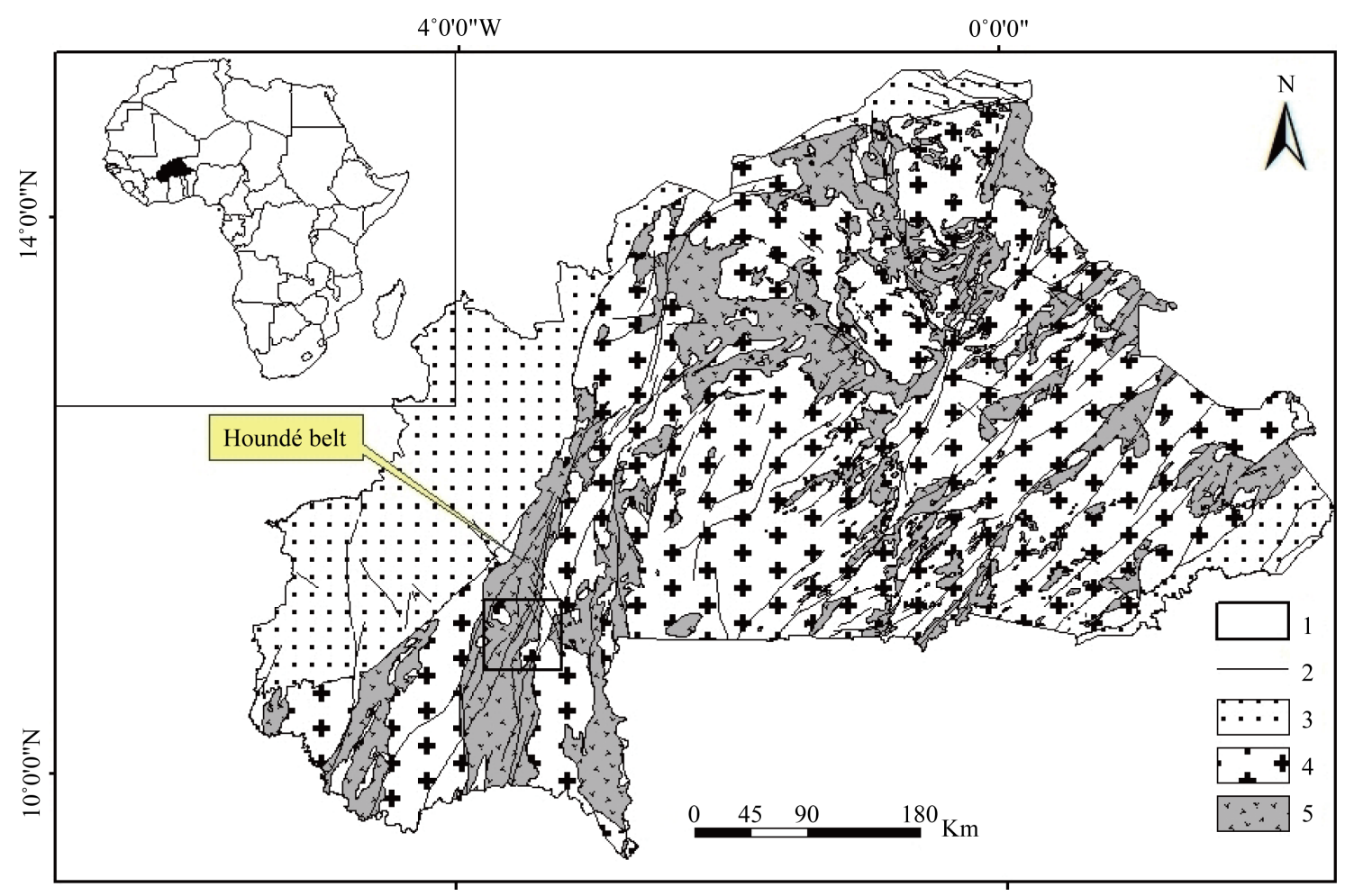

Figure 1. Global geological map of Burkina Faso (West Africa), showing Birimian [15]. 1: Study area; 2: Fault; 3: Neoproterozoic to paleozoic sedimentary basin; 4: Eburnean Granitic rock; 5: Birimien volcano-sedimentary rock.

East in its Northern and Western margins field of the Taoudeni and Voltaian basins. The Birimian basement is composed of volcanic and volcano-sedimentary rocks belts that are intruded by small ultrabasic to basic plutons and by wide masses of Eburnean granitoids. These greenstone belts form elongated strips towards the N-S or N-NNE-SSW direction extending into neighboring territories. In south-western Burkina Faso, the greenstone belts of Boromo and Houndé are the most extensive and curving under the shape of an arc or cross in the areas of Goren and Djibo controlled by transcurrent tectonic phases of (Feybesse et al., [21]). These Birimian belts consist of volcanic and volcano-sedimentary series and a deformed and metamorphosed sedimentary sequence comprising epizonal slate schists, greywacke, quartzite chert and black shales. These formations are intruded by small massifs of gabbro and peridotite.

On that subject, [8] [11] [15] consider the Birimian as a unit surmounted by a sedimentary detrital series attributed to the Tarkwaian. The latter includes arkosic sandstones and conglomerates.

The Tarkwaian in Burkina Faso form small strips along the Birimian belts heavily truncated and moved forward by a set of sinister accident Figure 2. The Tarkwaian of Intiedougou extends to Ivory Coast where it is called the Tehini groove [22]-[25]. The very intense Eburnean granitization hinders the development of TonaliteTrondhjemite-Granodiorite, Eburnean granite in the strict sense and post-kinematic calco alkaline to alkaline granites [15].

\section{Methodology}

The methodology is based on both field work and laboratory analysis. On the field, the geological sections were undertaken with a view to understanding the lithology, structure and relationships between Tarkwaian and Birimian. Laboratory investigations, geochemical analysis and petrographic study on 8 samples are taken from three sectors within the study area. After these two cuts in two sectors, five samples were taken for laboratory investigations articulated around thin-section petrographic samples made at the Laboratory of the University of Ouagadougou. Geochemical analyzes of major elements and trace of five (05) rock samples representing the Tarkwaian facies were carried out by the techniques of the ICP-MS at ACME Lab in Vancouver, Canada. 


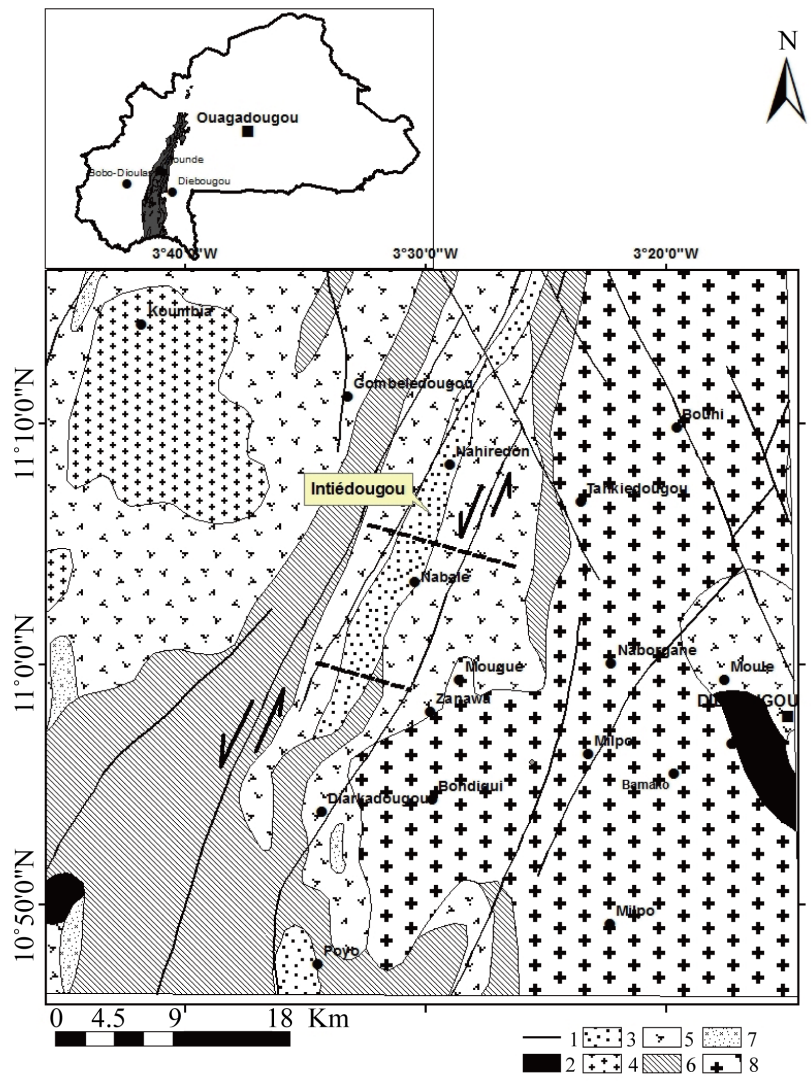

Figure 2. Simplified geological map of the Intiédougou area extracted of Castaing et al. [15]. (1) Fault; (2) Microdiorite and microgabbro; (3) Tarkwaian sedimentary rock (arkosic, sandstone, conglomerate); (4) Granitic rock; (5) Birimian Andesitic rock; (6) Birimian metasediment; (7) Birimian volcanoclastic rock; (8) Migmatite rock.

\section{Results and Discussion}

\subsection{Field Research}

Land sections were made in the NE-SW direction Figure 3 and Figure 4. The Intiédougou section begins with andesitic tuffs, volcanic breccias, lapilli tuffs intersected by a brecciated rhyolite dyke. In the SW direction appear some andesitic flowed in association with volcanic breccias with fragments of andesite and basalt rocks up to 15 $\mathrm{cm}$ in diameter, crossed by dikes of microgranites. The Tarkwaïan sedimentary formations are surrounded by the Birimian volcanic and volcano-sedimentary units and the contacts are on a mesoscopic or macroscopic scale.

At the outcrop in the area of Nahirindon, a frank and parallel contact between these units related to N-S accidents directed and operated by thalwegs namely in the Kobidja region (Figure 3). The most remarkable features of these units are the presence of pebbles from the Birimian rocks and misclassification of the sediments (Figure 5(b) and Figure 5(c)). The pebbles have very varied petrographic natures, they have an angular shape and are sometimes oval and can reach $20 \mathrm{~cm}$ in diameter. The graded bedding is generally normal but in the Intiédougou sector, it is reversed.

\subsection{Petrography}

The polygenic conglomerate is located about $1.5 \mathrm{~km}$ from the Intiédougou village towards the Bougouriba River. It is ash gray color composed of a little quartz-feldspar cement around pebbles of varied petrographic nature. The microscopic examination reveals a variety of pebbles, which confirms the polygenic nature: (i) andesites with spherolitic heteroganular porphyric to plagioclase texture embedded in a mesostasis rich in damourite and iron 


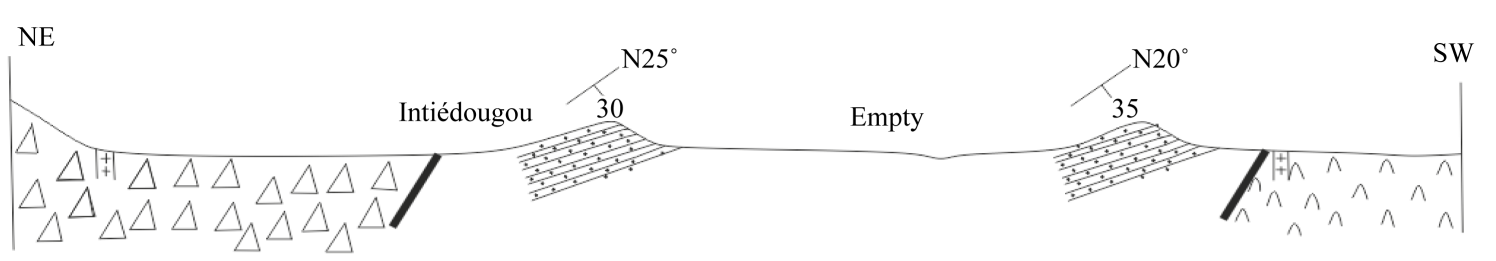

(a)

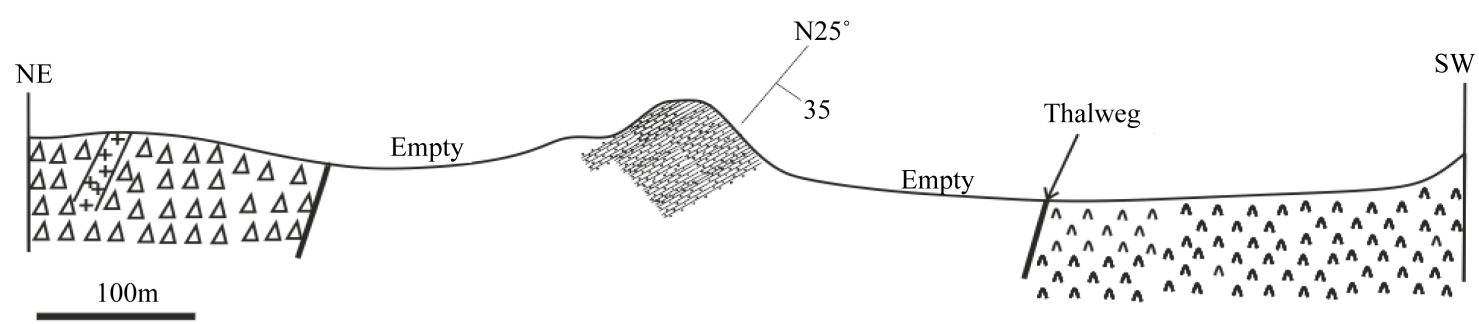

(b)

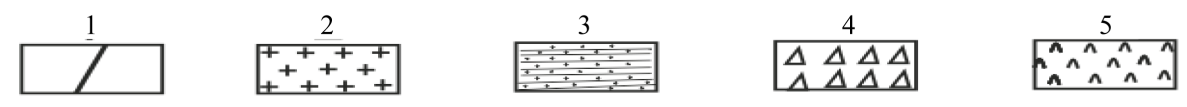

Figure 3. Geological cross sections in the study area. (a) Geological cross section of Intiédougou; (b) Geological cross section of Kobidja. 1: Fault; 2: Microgranite; 3: Tarkwaian formations; 4: Andesitic rock; 5: Volcanic breccia + tuff.
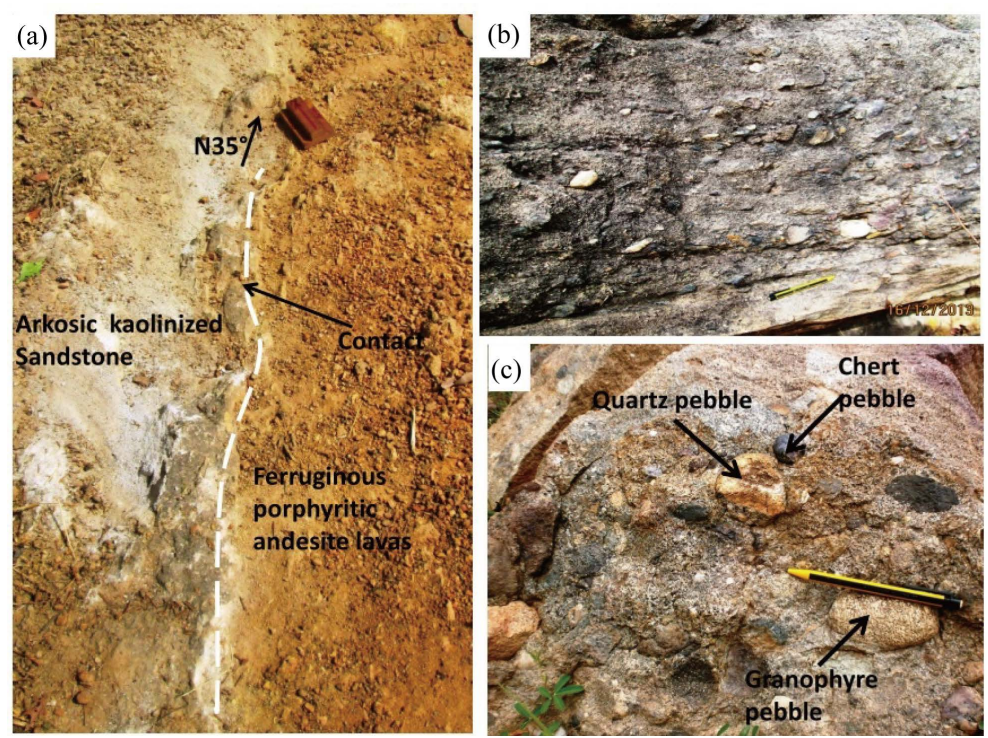

Figure 4. Photographs of the types of sedimentary rocks encountered in the study area. (a) Contact between fine to medium grain arkosic kaolinized sandstones and kaolinized to ferruginous porphyritic andesite lavas; (b) Polygenic microconglomerate of Zanawa with $5 \mathrm{~cm}$ pebbles; (c) Polygenic conglomerate of Zanawa with the presence of pebbles of different kinds.

oxide; (ii) Biotite hornfels with polygonal texture: the original rock underwent a granoblastic recrystallization and replaced by a microblaste feldspar mosaic. The matrix is rich in crystallized plagioclase sericite dotted with small strips of slightly destabilized biotite into chlorite and muscovite and opaque; (iii) Porphyroclastic spherolitic dacite with mylonite texture. The bottom is made up of fine to coarse clasts with plagioclase, biotite destabilized into opaque, chlorite and muscovite; (iv) Porphyric microdiorite sometimes of granophyric type, dacitic tuff, mylonite and quartz; (v) Crystal and/or lithic elements tuff.

Feldspathic sandstones: they form varied upper facies or the matrix of polygenic conglomerates pebbles. They contain lithic microfragments with a composition similar to macroscopic fragments. The petrographic analysis of 

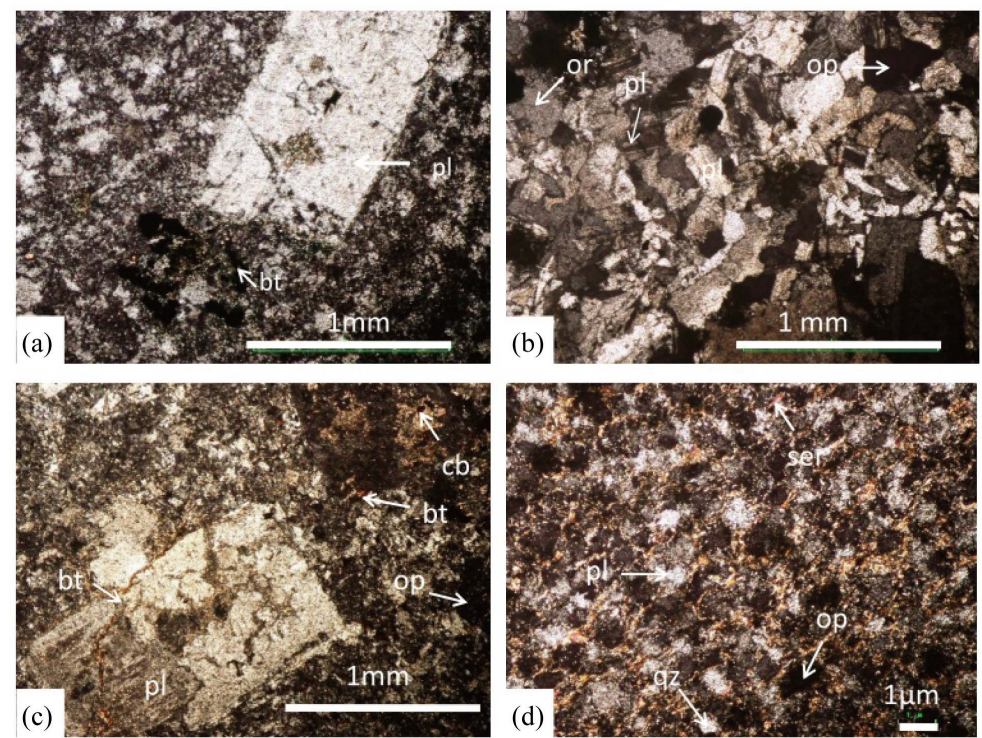

Figure 5. Microphotographs of the pebbles of the Birimian rocks in the conglomerates of the area. (a) Hydrothermalized spherulitic andesite formed of an aggregate of spherolites of plagioclase sticks; (b) Granoporphyric monzodiorite consisted of a combination of plagioclase and orthose; (c) Porphyric microdiorite consisted of albitized plagioclase often destabilized into carbonate; (d) Porphyroblastic spherulitic dacite made up of fine to coarse clasts with relicts of plagioclase spheroids. bt: biotite, pl: plagioclase, cb: carbonates, qz: quartz, ser: sericite, or: orthose, op: opaque.

these rocks reveals heterogranular texture with generally pelitic and phyllitic cement. These sandstones have a constant variation of fine to coarse grains passing by medium grain terms.

The fine facies contains angular heterogranular quartz crystals, plagioclase sometimes significant amount of (35\%) fully damouritized orthose with accessory biotite relicts associated with muscovite. The lithic fragments consist of porphyritic andesitic lavas and cherts, porphyritic microdiorites embedded in a sparse phyllitic cement rich in muscovite and sericite.

The middle facies presents a character that differs very slightly from the first by the size of the grains which are coarser, the presence of abundant enough opaque, lithic fragments marking the presence of diorites, of microdiorites and chert. These fragments are molded in abundant pelitic and hydrous mica cement.

The coarse facies is locally recrystallized into quartzite with hydrothermalized biotite. It has a coarse and massive grain size and well-preserved bedding, especially in the south of the area of Bonfesso. At a microscopic scale, the texture of the quartzite is heterogranular granoblastic serrated and meshed, with re-crystallized quartz crystals into sub meshed grains. The opaque and the muscovite highlight the fractures of the minerals and the rock (Figure 6).

\subsection{Sedimentological Character}

Despite the alteration, the Tarkwaian lands spared from the ductile shearing deformation clearly present primary sedimentological structures in terms of bedding. There is a bedding which is sometimes horizontal or tabular and rhythmic or laminate sometimes monoclinal or without any form of cross-bedded stratification. The thickness of the beds is of millimeter to centimeter order within thick decimeter to meter beds. The conglomerate sandstone beds and those of feldspathic sandstone in fine to coarse facies, sometimes silts show intercaltions of sandstone pudding however well exposed in the Zanawa region. In the Tarkwaian mounds of Intiédougou, the conglomeratic levels show lateral variations of facies marked by a decrease in the size and quantity of lithic pebbles.

The sandstone conglomerates rest in gully discrepancy on the sandstone levels and this arrangement demonstrates a negative polarity and an inverse grano-grading. We observe tracks of breccias with angular fragment of green lava or ferruginized with sandstone cement corresponding to collaterals of the Birimian rocks. The Tarkwaian formations described are generally not classified and immature sandstone terms. 

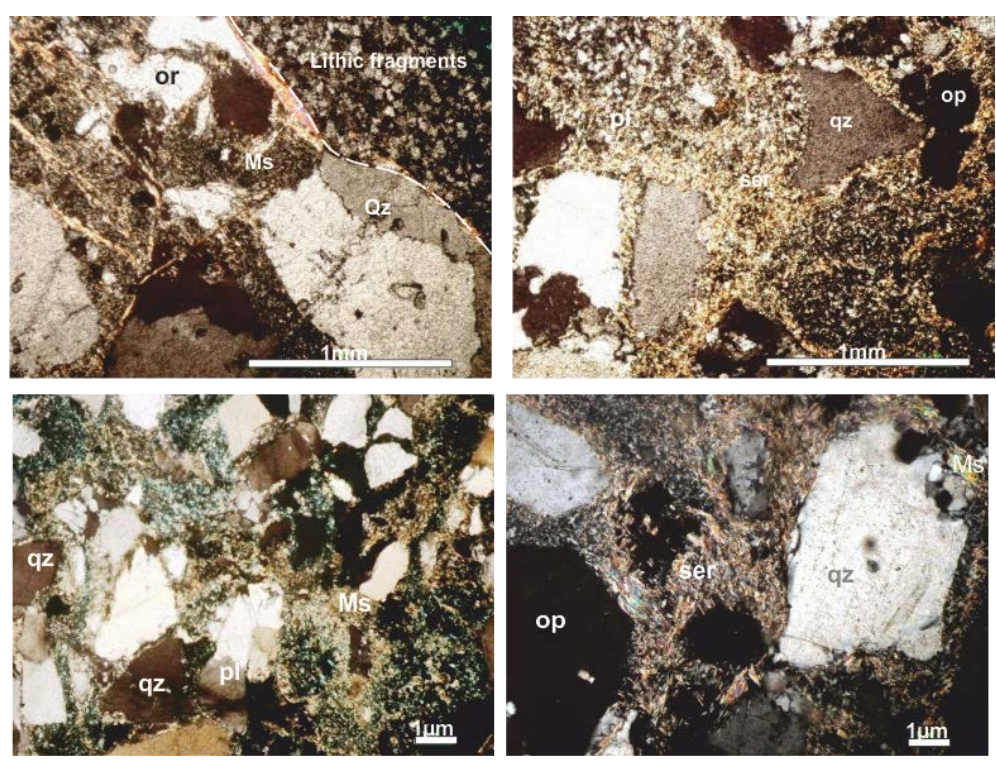

Figure 6. Micrograph of feldspathic sandstone. (1) Pelitic feldspathic sandstone consisted of angular quartz crackled with lithic fragments of biotite hornfels; (2) Feldspathic sericitous sandstones with abundant cement of pelite and hydromica in which are downed crystals of angular heterogranular quartz; (3) Hydro-mica feldspathic sandstone with crystals of angular heterogranular quartz dominant with lithic fragments; (4) Pelitic feldspathic sandstones with abundant cement consisted of quartz-feldspar and sericite. qz: quartz, pl: plagioclase, op: opaque, ser: sericite, ms: muscovite, or: orthose.

They are deducted from field observation of sedimentary Figure 4 that will enable an interpretation of the transportation and the depositional environment. On the field we observe the presence of poorly sorted coarse sediment, pebbles sometimes oval and oblique and intersecting stratifications and linear streaks (Figures 7(b)-(d)). The conclusions we can draw from these observations are the misclassification of sediments and the frequency of coarse and angular pebbles express a very short transportation.

This implies that the source of sediment would be very close to the depositional environment. The petrographic study shows that the pebbles of the conglomerate come from fragments of older rocks. The repeated presence of the oblique and cross-bedded stratification forming during the depositions of sediments shows either a fluvial transportation regime or torrential regime (Figure 6). In the petrographic analysis, there was high proportion of quartz and feldspar fragments on the one hand and on the other hand the abundance of lithic fragments mainly volcanic and sub-volcanic rocks that reflect the diversity of Birimian source eroded lands. All these arguments are in favor of a fluvial transportation regime whose deposition is much like those of torrential cones.

\subsection{Tectonics}

The deformation structures in the Tarkwaian system of the study area are much limited. At the outcrop some structural elements were inventoried. These elements are schistosity (S1) stratification (S0), the lineation of the pebbles according to the schistosity, pressure shadows, fractures and cracks. Rocks as a whole do not seem to be deformed due to the scarcity of structures. A well developed major schistosity S1 through the strip is observed. It is towards NNE-SSW direction with a dip that varies between $30^{\circ}$ and $60^{\circ}$ alternately at the NE and SW. To this cleavage is added a NNW-SSE direction crenulation cleavage at N-S and sloped at $80^{\circ}$. Schistosity S1 is superposed to the stratification in some places.

Microfolds can be observed as kink bands at Intiedougou. The surface of some quartz shows some striations of $\mathrm{N} 40^{\circ}$ overall direction whose extension ranges from $10^{\circ}$ to $20^{\circ}$ sub-horizontal. The presence of slits in echelon observed in the area of Zanawa and the stretching of the quartz pebbles sometimes fractured seems to indicate a shearing zone. The analysis of these structures suggests a NW-SE horizontal compression perpendicular to schistosity $\left(\mathrm{S}_{1}\right)$ and a horizontal extension NE-SW. The main constraint axis that caused this deformation seems to be a sinistral displacement or a gradual transition from a non-deformed area with a strongly deformed one. The 


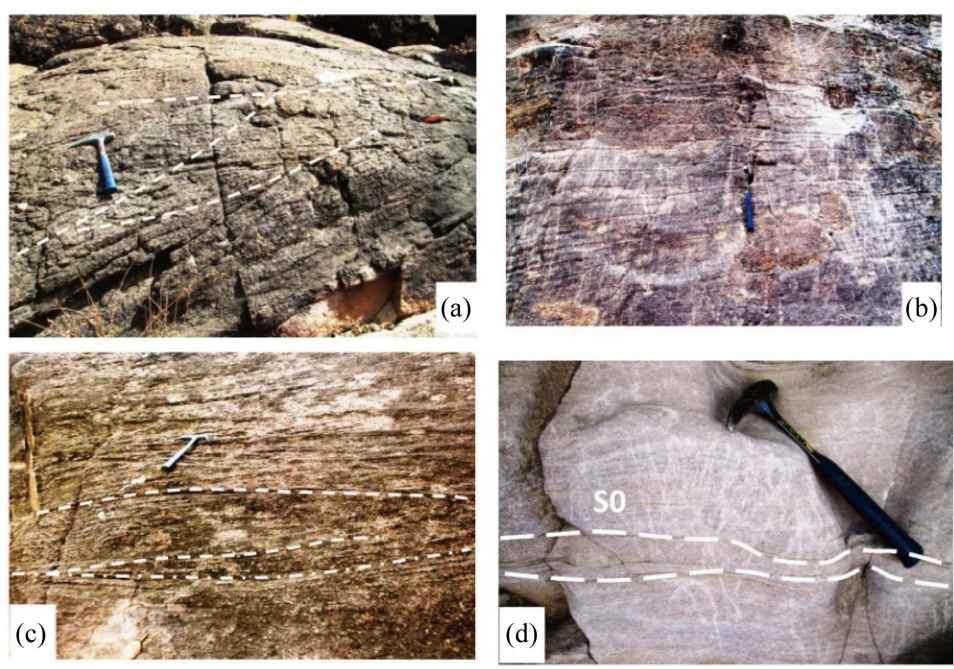

Figure 7. Photograph showing the sedimentologiccal characters of the depositions. (a) and (c): crossbedded stratification; (b) and (d): horizontal stratification; the S0 bedding observed on fine grain kaolinized feldspathic sandsones.

major event of deformation affecting formations known as Tarkwaian is the regional sheared schistosity $\left(\mathrm{S}_{1}\right)$. They are also affected by other styles of deformation ranging from semi-ductile to brittle whose result is superposed structures.

\subsection{Geochemistry}

The results of the chemical analyses of six (06) samples are shown in Table 1. The analysis of major elements and traces of Tarkwaian sediments shows that the sandstones show a normal siliceous character with contents of $\mathrm{SiO}_{2}$ between $80 \%$ and $88 \%$. The proportion of $\mathrm{Fe}_{2} \mathrm{O}_{3}$ varies from $2.29 \%$ to $4.29 \%$ and the proportions of $\mathrm{MgO}(\leq 1 \%)$ and $\mathrm{CaO}(<1 \%)$ are very low. The amounts of $\mathrm{Na}_{2} \mathrm{O}(0.011$ to 1.812$)$ and low $\mathrm{K}_{2} \mathrm{O}(1$ à 3$)$ could suggest intermediate mafic source.

The feldspathic sandstones of Intiédougou are richer in alumina (7\% - 110\%) than those of Bonfesso (average $5 \%)$. This difference is controlled by the amount of feldspar and mica. The iron oxides higher (4\%) in the sandstone of Bonfesso than in the sandstone of Intiédougou (2\% to 3.5\%) is accounted for by the quantity of the remainders of biotite and the opaques. Potash two to three times higher (in feldspathic sandstones of Intiédougou) is probably partly controlled by potassium feldspar and biotite white mica of these rocks. Some major elements exist in infinite quantity near their detection limit. The case of $\mathrm{CaO}$ shows the lack of basic plagioclase. The $\mathrm{Ba}$ values between 380 and 590 ppm higher in the feldspathic sandstones of Intiédougou are replaced by the plagioclase; the tungsten (W) imposes itself in some samples in proportions reaching $390 \mathrm{ppm}$.

The data of the major element analysis allowed from $\mathrm{Na}_{2} \mathrm{O}-\mathrm{MgO}-\mathrm{Fe}_{2} \mathrm{O}_{3}+\mathrm{K}_{2} \mathrm{O}$ [26] (Figure 8(a)) to show arkosic sandstones and lithic sandstones. This representation confirms the petrographic character highlighted above. In order to understand the origin of the sediments, in literature [27] proposed a discrimination diagram that considers seven (7) major elements $\mathrm{Al}_{2} \mathrm{O}_{3}, \mathrm{Fe}_{2} \mathrm{O}_{3}, \mathrm{TiO}_{2}, \mathrm{MgO}, \mathrm{K}_{2} \mathrm{O}, \mathrm{Na}_{2} \mathrm{O}$ and $\mathrm{CaO}$. They establish two functions F1 and F2 (Figure 8(b)) by using this diagram one easily understands that the represented samples probably originate from a mafic to intermediate source, which assumes the Birimian volcanic and subvolcanic formations.

The log chart $\left(\mathrm{K}_{2} \mathrm{O} / \mathrm{Na}_{2} \mathrm{O}\right)$ versus $\mathrm{SiO}_{2}$ Figure 8(c) [27] enables to separate the field of the oceanic insular arc, the field of the active continental margin and the passive margin. This diagram classifies the sediments of the study area in the field of the active continental margin. This diagram relates primarily to the maturity of the sediments. For mature clastic sediments are derived from the stable continental blocks and deposited in like rifts basins while immature sediments come from mixed sources and are stored on the active continental margin. The representation of the composition of the points of the samples indicates a signature of active continental margin.

The ternary Th-Sc-Zr/10 diagram [28] using and La-Th-Sc diagram Figure 9 a signature of the oceanic island arc agrees with the geodynamic Birimian context. The representation of the multi-elements spidergram of the samples of normalized $\mathrm{N}=1$ sandstone [29] shows that most of the samples of the study area are depleted in $\mathrm{Rb}, \mathrm{Sr}$ 
Y. H. Koffi et al.

Table 1. Analysis of major elements (\%), trace elements (ppm) and rare earth (ppm) of sedimentary rocks in the study area.

\begin{tabular}{|c|c|c|c|c|c|c|}
\hline & HK10 & D2 & HK17 & HK13A & C5 & D60P18 \\
\hline & \multicolumn{2}{|c|}{ Quartzite sandstone } & \multicolumn{3}{|c|}{ Feldspathic sandstone } & Sandstone \\
\hline & \multicolumn{2}{|c|}{ Bonfesso } & \multicolumn{3}{|c|}{ Intiédougou } & Djarkadougou \\
\hline $\mathrm{SiO}_{2}$ & 86.76 & 88.09 & 80.75 & 85.90 & 83.53 & 80.47 \\
\hline $\mathbf{A l}_{2} \mathbf{O}_{3}$ & 5.31 & 5.03 & 10.22 & 7.66 & 8.64 & 9.18 \\
\hline $\mathrm{Fe}_{2} \mathrm{O}_{3}$ & 4.29 & 3.98 & 3.45 & 2.29 & 2.74 & 2.92 \\
\hline $\mathrm{TiO}_{2}$ & 0.40 & 0.40 & 0.30 & 0.22 & 0.19 & 0.25 \\
\hline MgO & 0.08 & 0.08 & 0.15 & 0.10 & 0.16 & 0.46 \\
\hline $\mathbf{K}_{2} \mathbf{O}$ & 1.07 & 1.13 & 3.09 & 1.95 & 2.83 & 1.91 \\
\hline $\mathrm{CaO}$ & 0.02 & 0.03 & 0.02 & 0.02 & 0.06 & 0.92 \\
\hline $\mathrm{Na}_{2} \mathrm{O}$ & 0.17 & 0.25 & 0.07 & 0.15 & 0.04 & 1.81 \\
\hline $\mathbf{P}_{2} \mathbf{O}_{5}$ & 0.05 & 0.03 & 0.04 & 0.06 & 0.03 & 0.06 \\
\hline MnO & 0.01 & 0.01 & $<0.01$ & $<0.01$ & 0.01 & 0.04 \\
\hline $\mathrm{Cr}_{2} \mathrm{O}_{3}$ & 0.018 & 0.007 & 0.011 & 0.006 & 0.004 & 0.004 \\
\hline LOI & 1.7 & 0.9 & 1.8 & 1.5 & 1.7 & 1.9 \\
\hline Sum & 99.878 & 99.937 & 99.86 & 99.87 & 99.934 & 99.924 \\
\hline \multicolumn{7}{|c|}{ Trace elements } \\
\hline $\mathbf{N i}$ & 38 & $<20$ & $<20$ & $<20$ & $<20$ & $<20$ \\
\hline Sc & 7 & 5 & 6 & 5 & 4 & 5 \\
\hline $\mathbf{B a}$ & 381 & 385 & 544 & 583 & 509 & 380 \\
\hline Be & $<1$ & $<1$ & $<1$ & 2 & 2 & $<1$ \\
\hline Co & 58.7 & 4.8 & 47.2 & 48.8 & 4.6 & 5.8 \\
\hline Cs & 1.2 & 0.9 & 8.9 & 1.6 & 6.6 & 2.2 \\
\hline Ga & 6.3 & 7.9 & 9.9 & 8.0 & 9.7 & 8.4 \\
\hline Hf & 2.7 & 2.1 & 1.9 & 1.7 & 1.7 & 1.9 \\
\hline $\mathbf{N b}$ & 3.2 & 3.6 & 3.2 & 2.5 & 3.3 & 2.7 \\
\hline $\mathbf{R b}$ & 33.8 & 32.9 & 80.2 & 56.5 & 71.5 & 48.0 \\
\hline Sn & 1 & $<1$ & $<1$ & $<1$ & 1 & $<1$ \\
\hline $\mathrm{Sr}$ & 52.2 & 50.6 & 52.9 & 120.1 & 33.9 & 109.0 \\
\hline $\mathbf{T a}$ & 0.6 & 0.2 & 0.6 & 0.6 & 0.3 & 0.3 \\
\hline Th & 2.3 & 2.1 & 3.5 & 2.1 & 2.5 & 2.6 \\
\hline $\mathbf{U}$ & 0.8 & 0.5 & 0.6 & 0.4 & 0.1 & 0.5 \\
\hline $\mathbf{V}$ & 80 & 75 & 41 & 44 & 29 & 39 \\
\hline $\mathbf{W}$ & 388.7 & 1.0 & 345.5 & 367.6 & 24.5 & 1.2 \\
\hline $\mathrm{Zr}$ & 100.5 & 82.5 & 66.7 & 51.9 & 58.4 & 70.7 \\
\hline
\end{tabular}




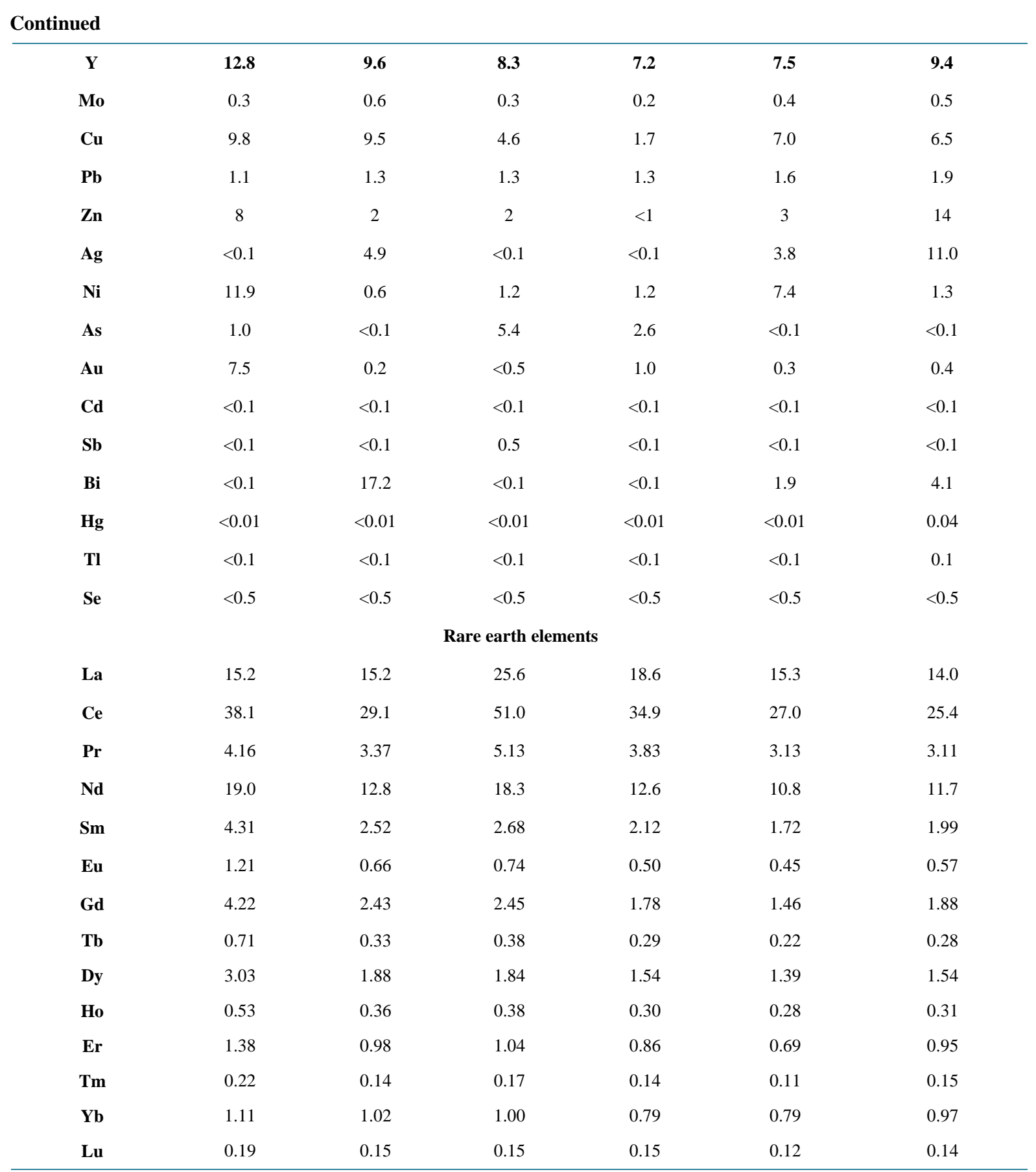

and $\mathrm{P}$ probably close to a light contribution the continental crust Figure 10. The sharp depression of the uranium in a sandstone sample could be explained by the process of alteration and the recycling of source rocks resulting from the clastics terrigenous sediments. Sr and Tb deficiency shows the scarcity of the plagioclase in the sample. $\mathrm{K}, \mathrm{Ba}$, and $\mathrm{Nd}$ enrichment are due to greater accumulation of the feldspars and micas.

\section{Discussion}

\subsection{Correlation with Ghana Tarkwaian}

Sedimentary detrital deposits made up of polygenic sandstone conglomerates, sandstone or pudding micro- 
(a)

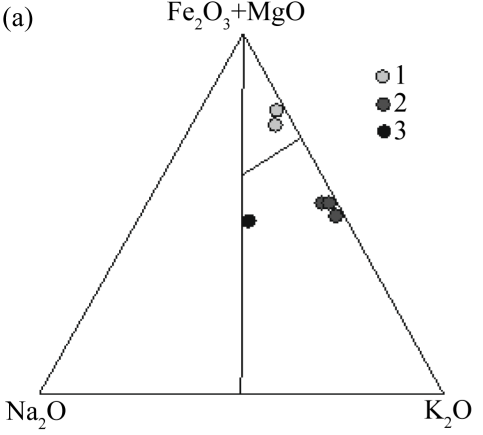

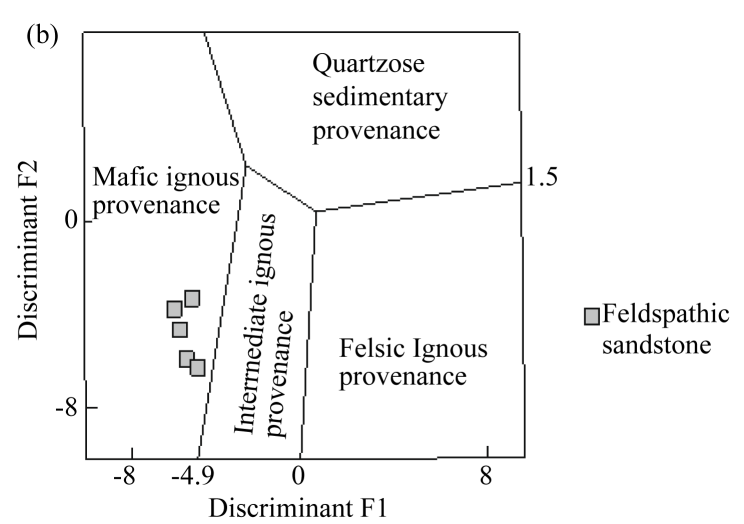

(c)

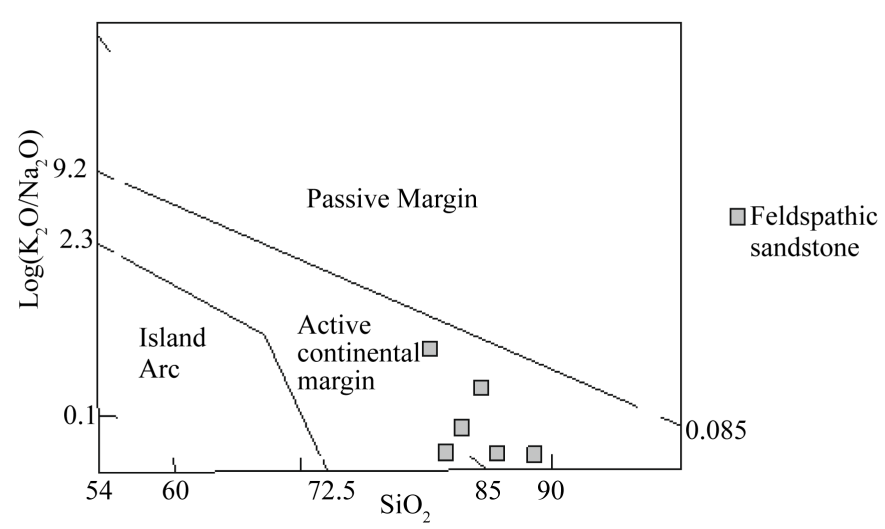

Figure 8. The source of the feldspathic sandstones of the study area showing a signature of the oceanic continental arc. (a) Class of sediments in the diagram of [26]; (b) Discrimination diagram of the same authors. Discriminant Function $1=-1.773 \mathrm{TiO}_{2}+0.607 \mathrm{Al}_{2} \mathrm{O}_{3}+0.76 \mathrm{Fe}_{2} \mathrm{O}_{3}(\mathrm{t})-1.5 \mathrm{MgO}+0.616 \mathrm{CaO}+$ $0.509 \mathrm{Na}_{2} \mathrm{O}-1.224 \mathrm{~K}_{2} \mathrm{O}-9.09$; Discriminant Function $2=0.445 \mathrm{TiO}_{2}+0.07 \mathrm{Al}_{2} \mathrm{O}_{3}-0.25 \mathrm{Fe}_{2} \mathrm{O}_{3}(\mathrm{t})-$ $1.142 \mathrm{MgO}+0.438 \mathrm{CaO}+1.475 \mathrm{Na}_{2} \mathrm{O}+1.426 \mathrm{~K}_{2} \mathrm{O}-6.861$; (c) Diagram of (Roser and Korsch, [27]).
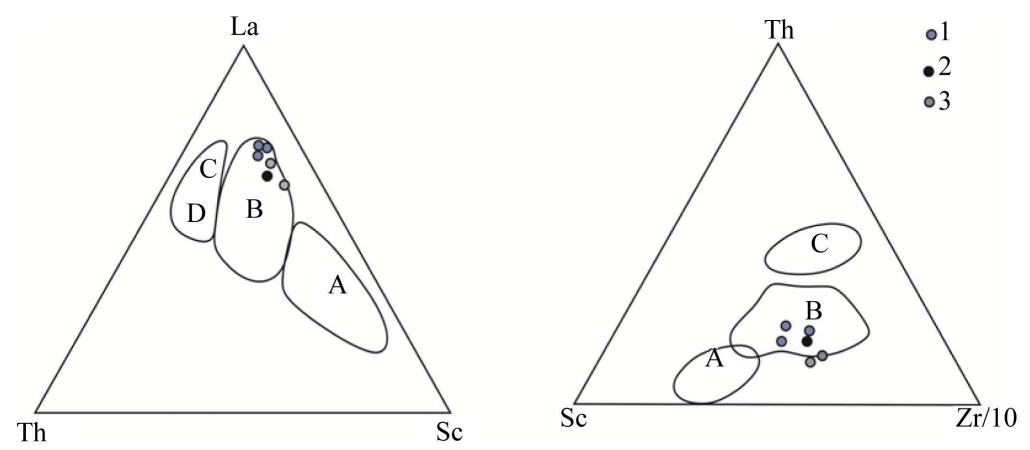

Figure 9. Discrimination diagram for sandstone of study area (Bathia and Crook, 1986). The field are: A: oceanic island arc; B: continental island arc; C: active continental margin; D: passive margin. 1: sandstone of bonfesso; 2: sandstone of Intiédougou; 3: sandstone of Djarkadougou.

conglomerate, sedimentary breccia and feldaspathic sandstones with fine, medium to coarse facies form thin strips alongside the Birimian belts, Houndé belt in particular.

These formations have been described by (Bonkoungou, [13]; Bossière et al., [14]; Baratoux et al., [30]) and attributed to the "Tarkwaian" system on the basis of petrological correlation especially with conglomeratic levels. Comparing these formations to the reference Tarkwaian (Table 2) where the lithostratigraphy begins with the Kawere group conglomerate, the quartzites group of the Banket, the phyllite group of Tarkwa and ends with the Huni sandstone. At the stage of the current knowledge on the field, it is difficult to find the equivalent of all the 


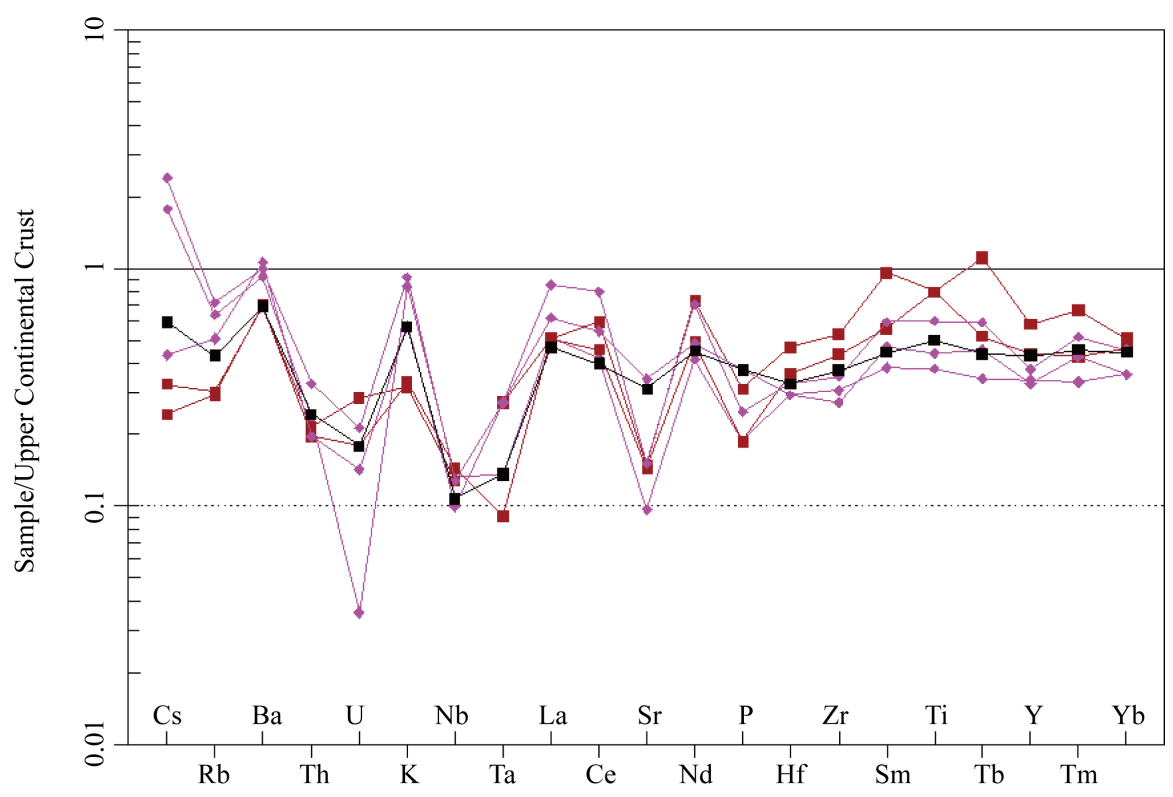

Figure 10. Spidergram of Tarkwaien formations of the study area deposits [29] normalized $\mathrm{N}=1$.

Table 2. Comparison of the Ghana Tarkwaian to the Tarkwaian formations of Burkina-Faso.

\begin{tabular}{|c|c|c|c|c|c|c|}
\hline Authors & Location & Stratigraphic Unit & Alterations & Pebbles & Age (Ma) & Interpretations \\
\hline \multirow{3}{*}{ 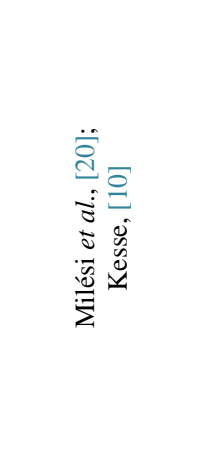 } & Bottom & $\begin{array}{c}\text { Sandstone, } \\
\text { polygenic } \\
\text { conglomerates }\end{array}$ & $\begin{array}{c}\text { Silicification + } \\
\text { carbonates }\end{array}$ & \multirow{3}{*}{$\begin{array}{l}\text { Quartz and meta- } \\
\text { volcanites }\end{array}$} & \multirow{3}{*}{ 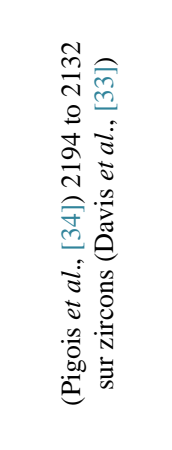 } & \multirow{3}{*}{$\begin{array}{l}\text { Tectonics: rift basins } \\
\text { Environment: Fluvial } \\
\text { Source: Birimian rocks }\end{array}$} \\
\hline & \multirow{2}{*}{ 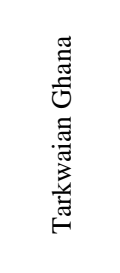 } & \multirow{2}{*}{$\begin{array}{l}\text { Quartzite sandstone, } \\
\text { oligomictic } \\
\text { conglomerates, } \\
\text { sandstone } \\
\text { Phyllites }\end{array}$} & \multirow[t]{2}{*}{$\begin{array}{c}\text { Sericite }+ \text { chlorite }+ \\
\text { epidote }+ \text { biotite }+ \\
\text { ankerite }\end{array}$} & & & \\
\hline & & & & & & \\
\hline 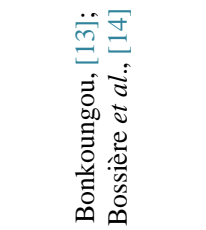 & \multirow{3}{*}{ 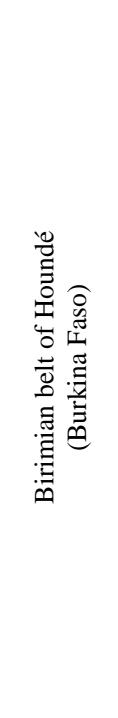 } & $\begin{array}{c}\text { Pelites, } \\
\text { sandstone- quartzite, } \\
\text { polygenic } \\
\text { conglomerates }\end{array}$ & $\begin{array}{c}\text { Muscovite + } \\
\text { chlorite + sericite }\end{array}$ & $\begin{array}{l}\text { Quartz, schists, } \\
\text { acidic } \\
\text { metavolcanites }\end{array}$ & $\begin{array}{l}2170 \pm 7 \text { to } \\
2124 \pm 9 \text { over } \\
\text { zircons }\end{array}$ & $\begin{array}{c}\text { Tectonics: Graben } \\
\text { associated with a rift } \\
\text { Environment: Fluvial + } \\
\text { acidic pyroclastic clastic } \\
\text { Source: volcanic and } \\
\text { clastic rocks }\end{array}$ \\
\hline Sinaré, [35] & & $\begin{array}{c}\text { Pelite lithic wackes, } \\
\text { polygenic } \\
\text { conglomerates }\end{array}$ & $\begin{array}{c}\text { Sericite }+ \\
\text { silicification }+ \\
\text { carbonates }\end{array}$ & $\begin{array}{l}\text { Quartz, rhyolites, } \\
\text { volcanites, } \\
\text { Porphyre }\end{array}$ & ? & $\begin{array}{c}\text { Tectonics: supra-subduction } \\
\text { Environment: marine deltaic } \\
\text { margin + volcanic arc } \\
\text { Source: mafic and felsic } \\
\text { rocks }\end{array}$ \\
\hline The present work & & $\begin{array}{l}\text { Pelitic feldspathic } \\
\text { sandstones } \\
\text { Polygenic } \\
\text { conglomerates }\end{array}$ & $\begin{array}{c}\text { Hydro-micas } \\
\text { (muscovite type) + } \\
\text { sericite + opaques }\end{array}$ & $\begin{array}{l}\text { Quartz, mylonite, } \\
\text { porphyric } \\
\text { microdiorite and } \\
\text { dacitic spherolitic } \\
\text { tufs }\end{array}$ & ? & $\begin{array}{c}\text { Tectonics: fluvial + } \\
\text { volcanic and pyroclastic } \\
\text { rocks } \\
\text { Environment: + continental } \\
\text { margin + volcanic arc } \\
\text { Source: mafic and } \\
\text { intermediate rocks, context } \\
\text { of continental intra chain } \\
\text { rifts }\end{array}$ \\
\hline
\end{tabular}


units in Burkina Faso. In this country and the neighboring regions, these units defined in Ghana could correspond to lateral or longitudinal variations of facies. Sedimentary rocks contain fragments of volcanic and volcano- sedimentary and volcanic rocks, hornfel, mylonite, quartz and feldspar that probably come from the erosion of the surrounding rocks. The geochemical character indicates that the sediments originate from mafic to intermediate source and the geotectonic context would be in an active continental margin. This seems to be close to the model of Baratoux et al. [30]. In their geodynamic model on the greenstone belts in the south-western Burkina Faso, Baratoux et al. [30] presented two scenarios: (1) each of the Southwest belts approximately corresponds to a volcanic arc and (2) the other to a single large arc consisted of undifferentiated granitoids within.

The structural will be established during a first tectonic sheared phase and the low-intensity second phase which tighten the whole set. The sediments of the area consist of a mixture of volcano-detrital and volcanic elements in varying proportions. The geodynamic significance of this volcanism could be attached to syntectonic parameters leading to the formation of rifting or pull apart type basins. These riftings will be the seat of the clastic and volcanic sediments. From a structural perspective (Castaing et al., [15], Bonkoungou, [13], Milesi et al., [20]) agree on the existence of an angular unconformity between the Birimian and the Tarkwaian in the south-west of Burkina Faso. They use structural arguments namely the dip difference between the first subvertical and oblique for the second to show the existence of a mega bend whose flank may have preceded dipping of $45^{\circ}$ to justify the assumptions.

From a geochronological point of view, scattered U/Pb ages obtained on detritical zircon in Ghana $2081 \pm 25$ and $1968 \pm 49$ Ma by (Hirdes et al. [31] [32]) and 2194 - $2132 \pm 20$ Ma by (Davis et al. [33]) are similar with the ages found in Burkna Faso by (Bonkoungou, [13]) $2151 \pm 20$ Ma $1991 \pm$ Ma suggest multivariable source of birimian rocks and contribution to Tarkwaian deposits. The differences can be found in the interpretation of geodynamic contexts of the regions.

In the Kobidja area, the Birimian volcanic-Tarkwaian clastic contact appears to be frank and parallel. An angular structural and non-stratigraphic unconformity is admissible considering the rectified character of the sheared volcanics and the $\mathrm{S}_{0}$ stratification structures of the sandstones surrounding and in contact.

\subsection{Birimian Mineral and Lithics Signature in the Tarkwaian Formations}

The basic and felsic volcanic and hypovolcanic formations and their associated quartz veins of the Birimian chains are the main source of the Tarkwaian sediments. The quartz and chert pebbles and the more or less rolled fragments of microdiorite, diorite and microgranite alternating from this Birimian contribution is the same for volcanoclastite with dacitic tuffs with crystals and dominant lithic elements, rhyolitic and arenite tuffs less often. The abundance of debris of spherolitic dacitic flows and spherolitic to porphyry microlithic andesites in these terrigenous sediments is correlated with the predominance of these facies in the Birimian volcanism. The majority of these lithic fragments underwent shear deformation and hydrothermal alteration rather than metamorphism. These assumptions are corroborated by the presence of volcanic quartz that is gulfed or twinned or even in the form of dagger blade. Although limited, the participation of the granite base is conceivable whose marks are found in coarse quartz debris poecilitic igneous of plagioclase polycrystalline debris or in digestion, the quartz fragment in mosaic. The contribution of old birimiandetrital sediments or volcano-sediments is still to be elucidated with physico-chemical tracers.

\subsection{Geodynamics}

The calc-alkaline geochemical signatures of the Birimian volcanics and their subvolcanic vein associated Eburnean granites are like emanations of geodynamic contexts of intra-oceanic subduction with insular arc [15]. The products derived from these formations may have influenced the composition and the definition of the geodynamic setting of the island arc of the Tarkwaian sediments. This model is accepted by authors who supported it with lithostructural arguments especially for the greenstone belts of the West and Southwest of the country. The structuring of the Birimian system is induced by a first phase of ductile brittle shearing around 2100 Ma, known in the West as the Houndé-Ouahigouya rift and in the East as the Markoye-Tiébélé rift have regional extension. These accidents have worked in multiple tectonic reactivations to which are likely linked rifts, a megastructure favourable to the deposits of the Tarkwain terrigenous sediments [15]. 


\section{Conclusions}

The Tarkwaian deposits of purely detrital nature form in Burkina Faso narrow strips spread one hundred kilometers along the volcano-sedimentary Birimian belts. The Intiédougou Tarkwaian strips located in western Burkina Faso form mounds accessible by geological cross sections enabling to identify the main facies and their sedimentological character. These formations essentially consisted of polygenic sandstone conglomerate, puddings, heterometric pelitic feldspathic sandstone with fine to coarse grains with locally intercalated passes of sedimentary breccias with lithic pebbles and macroscopic and microscopic fragments are similar to the vein-type originated quartz, andesitic and dacitic rocks and projection, subvolcanic felsic rocks of microdioritic to microgranite composition. In non-disturbed areas sedimentological features are preserved through monocline and cross bedded horizontal stratification and fine grain coarse bedding. Sections reveal between the benches of the main facies, a gully misalignment between the polygenic conglomerates and sandstones highlighting the discordant tectonic contacts with the Tarkwaian and the Birrimian.

Geochemically, the composition of majors and trace elements is influenced by the relative decline of the dominant quartz of feldspars and phyllites. The inadequately classified and immature feldspathic sandstones show affinities of insular arc contexts probably dictated by Birimian lithic products. The extent of volcanic and subvolcanic fragments in terrigenous sediments leads to conclude a major contribution of Birimian volcano-sedimentary series without excluding the minor contribution of the granitic basement. The cross-bedded stratification and the predominance of sandstone terrigenous facies suggest a deposit in a fluvio-deltaic hydrodynamic setting along the Birimian intermontane rift. The similarity between these Tarkwaian deposits and the typical Tarkwaian of the Tarkwa basin in Ghana is possibly limited to the petrographic and no-stratigraphic aspects, which leads to liken them in Burkina-Faso to Birimian flyschoïds or molassics tardi depositions.

\section{Acknowledgements}

I would like to express my dear acknowledgement to all those who contributed to the preparation of this article and especially U. Wenmenga of Ouagadougou University Pr. Joseph Ki Zerbo and Ch. Djro of Felix Houphouet Boigny university Cocody.

\section{References}

[1] Junner, N.R. (1940) Geology of the Gold Coast and Western Togoland (with Revised Geological Map). Gold Coast Geological Survey Bulletin No. 11, 75 p.

[2] Roques, H. (1948) Le Précambrien de l’Afrique Occidentale Française. Bulletin de la Société géologique de France, 5, 589-628.

[3] Sestini, G. (1973) Sedimentology of a Paleoplacer: The Gold-Bearing Tarkwaian of Ghana. International Union of Geological Sciences Series A, 3, 275-305. http://dx.doi.org/10.1007/978-3-642-65329-2_21

[4] Kesse, G.O. (1986) Les formations birimiennes en Afrique de 1'Ouest. The Birimian System in Ghana. Centre International pour la Formation et les Echanges en Geoscience, 10, 7-29.

[5] Cahen, L., Sneiling, N.J., Delhal, J., Bonhomme, M. and Ledent, D. (1984) The Geochronology and Evolution of Africa. Clarendon Press, Oxford, 512 p.

[6] Kitson, A.E. (1928) Provisional Geological Map of the Gold Coast and Western Togoland, with Brief Descriptive Notes Thereon. Sir Ranford Slater, Governor of the Gold Coast, London.

[7] Whitelaw, O.A.L. (1929) Geological and Mining Features of the Tarkwa-Abosso Goldfield. Geological Survey, Accra, 45 p.

[8] Hirdes, W. and Nunoo, B. (1994) The Proterozoic Paleoplacers at Tarkwa Gold Mine, SW Ghana: Sedimentology, Mineralogy, and Precise Age Dating of the Main Reef and West Reef, and Bearing of the Investigations on Source Area Aspects. Geologisches Jahrbuch, D100, 247-311.

[9] Archamaut, T.J. (1934) Rapport géologique provisoire sur la région de Dimbokro-Toumodi-Agboville-Tiassalé-OuméBouaflé-Dakar, services des mines de l'Afrique Occidentale Française, dactylograhie, Archive Société pour le Développement des Mines de Côte d'Ivoire, 38 p.

[10] Wright, J.B., Hastings, D., Jones, W.B. and Williams, H.R. (1985) Geology and Mineral Resources of West Africa. Allen and Unwin, London.

[11] Sagatsky, J. (1937) Le système Tarkwaien en Haute-Volta. Comptes Rendus de l'Académie des Sciences, Paris, 205 p. 
[12] Marcelin, J. (1971) Notice explicative de al carte géologique au 1/200000 Gaoua-Batié. BRGM, Orleans.

[13] Bonkoungou, I. (1994) Le Tarkwaien du sillon de Houndé (Burkina-Faso): Un ensemble volcano-détritique acide calcoalcalin à $2.15 \mathrm{Ga}$. Etude pétrologique, métamorphique et structurale. Université de Nantes, Nantes.

[14] Bossière, G., Bonkoungou, I., Peucat, J.J. and Pupin, J.P. (1996) Origin and Age of Paleoproterozoic Conglomerates and Sandstones of the Tarkwaian Group in Burkina Faso, West Africa. Precambrian Research, 80, 153-172. http://dx.doi.org/10.1016/S0301-9268(96)00014-9

[15] Castaing, C., Bila, M., Milési, J.-P., Thiéblemont, D., Le Metour, J., Egal, E., Donzeau, M., Guerrot, C., Cocherie, A., Chevremont, P., Teygey, I., Itard, Y., Zida, B., Ouédraogo, I., Koté, S., Kabore, B.-E., Ouédraogo, C., Ki, J.-C. and Zunino, C. (2003) Notice explicative de la carte géologique et minière du Burkina Faso à 1/1000 000. 3 ème édition, BRGM, Orléans, France, 148 p.

[16] John, T., Klemd, R., Hirdes, W. and Loh, G. (1999) The Metamorphic Evolution of the Paleoproterozoic (Birimian) Volcanic Ashanti Belt (Ghana, West Africa). Precambrian Research, 98, 11-30. http://dx.doi.org/10.1016/S0301-9268(99)00024-8

[17] Schmidt Mumm, A., Oberthür, T., Vetter, U. and Blenkinsop, T.G. (1997) High $\mathrm{CO}_{2}$ Content of Fluid Inclusions in Gold Mineralisations in the Ashanti Belt, Ghana: A New Category of Ore Forming Fluids? Mineralium Deposita, 32, 107-118. http://dx.doi.org/10.1007/s001260050078

[18] Bard, J.P. (1974) Remarques à propos de l'évolution géotectonique du craton ouest-africain en Côte d'Ivoire. Comptes Rendus de l'Académie des Sciences, 278, 2405-2408.

[19] Lemoine, S. (1988) Evolution géologique de la région de Dabakala (NE Côte d’Ivoire) au Protérozoïque inférieur. Université Clermont-Ferrand, 338.

[20] Milési, J.P., Feybesse, J.L., Ledru, P., Dommanget, A., Quedraogo, M.F., Marcoux, E., Prost, A., Vinchon, C., Sylvain, J.P., Johan, V., Tegyey, M., Calvez, J.Y. and Lagny, P. (1989) Les minéralisations aurifères de l'Afrique de l’Ouest. Leurs relations avec l'évolution lithostructurale au Protérozoïque inférieur. Chronique de la Recherche Minière, 497, 3-98.

[21] Feybesse, J.L., Milési, J.-P., Johan, V., Dommanget, A., Calvez, J.-Y., Boher, M. and Abouchami, W. (1989) The Archean/Lower Proterozoic Boundary of West Africa: A Major Thrust Area Predating the Sassandra Fault; Example of the Odienné and Touba Regions (Ivory Coast). Comptes Rendus Geoscience, 309, 1847-1853.

[22] Vidal, M., Delor, C., Pouclet, A., Siméon, Y. and Alric, G. (1996) Evolution géodynamique de l’Afrique de l’Ouest entre 2.2 Ga et $2 \mathrm{Ga}$; le style "archéen” des ceintures vertes et des ensembles sedimentaires birimiens du nord-est de la Côte-d’Ivoire. Bulletin Société Géologiques France, 167, 307-319.

[23] Vidal, M., Gumiaux, C., Cagnard, F., Pouclet, A., Ouattara, G. and Pichon, M. (2009) Evolution of a Paleoproterozoic "Weak Type" Orogeny in the West African Craton (Ivory Coast). Tectonophysics, 477, 145-159. http://dx.doi.org/10.1016/j.tecto.2009.02.010

[24] Lüdtke, G., Hirdes, W., Konan, G., Koné, Y., Yao, C., Diarra, S. and Zamblé, Z. (1998) Géologie de la région Haute Comoé Nord-Feuilles Kong (4b et 4d) et Téhini-Bouna (3a à 3d). Direction de la Géologie Abidjan Bulletin, Abidjan.

[25] Lüdtke, G., Hirdes, W., Konan, G., Koné, Y., N’da, D., Traore, Y. and Zamblé, Z. (1999) Géologie de la région Haute Comoé Sud-Feuilles Dabakala (2b, d et 4b, d). Direction de la Géologie Abidjan Bulletin, Abidjan.

[26] Blatt, H.G., Middleton, G.V. and Murray, R.C. (1980) Turbidites. Development in Sedimentology 3. Elsevier Publishing Company, San Diego, 264 p.

[27] Roser, B.P. and Korsch, R.J. (1988) Provenance Signatures of Sandstone-Mudstone Suites Determined Using Discriminant Function Analysis of Major-Element Data. Chemical Geology, 67, 119-139. http://dx.doi.org/10.1016/0009-2541(88)90010-1

[28] Bhatia, M.R. and Crook, K.A.W. (1986) Trace Element Characteristics of Graywackes and Tectonic Setting of Sedimentary Basins. Contributions to Mineralogy and Petrology, 92, 181-193. http://dx.doi.org/10.1007/BF00375292

[29] Taylor, S.R. and McLennan, S.M. (1995) The Continental Crust: Its Composition and Evolution. Blackwell, Oxford.

[30] Baratoux, L., Metelka, V., Naba, S., Mark, W.J., Michel, G. and Jérôme, G. (2011) Juvenile Paleoproterozoic Crust Evolution during the Eburnean Orogeny ( 2.2 - 2.0 Ga), Western Burkina Faso. Precambrian Research, 191, 18-45. http://dx.doi.org/10.1016/j.precamres.2011.08.010

[31] Hirdes, W., Davis, D.W. and Eisenlohr, B.N. (1992) Reassessment of Proterozoic Granitoid Ages in Ghana on the Basis of U/Pb Zircon and Monazite Dating. Precambrian Research, 56, 89-96. http://dx.doi.org/10.1016/0301-9268(92)90085-3

[32] Hirdes, W. and Davis, D.W. (1998) First U-Pb Zircon Age of Extrusive Volcanism in the Birimian Supergroup of Ghana/West Africa. Journal of African Earth Sciences, 27, 291-294. http://dx.doi.org/10.1016/S0899-5362(98)00062-1

[33] Davis, D.W., Hirdes, W., Schaltegger, U. and Nunoo, E.A. (1994) U-Pb Age Constraints on Deposition and Prove- 
nance of Birimian and Gold-Bearing Tarkwaian Sediments in Ghana West Africa. Precambrian Research, 67, 89-107. http://dx.doi.org/10.1016/0301-9268(94)90006-X

[34] Pigois, J.P., Groves, D.I., Fletcher, I.R., McNaughton, N.J. and Snee, L.W. (2003) Age Constraints on Tarkwaian Paleoplacer and Lode-Gold Formation in the Tarkwa-Damang District, SW Ghana. Mineralium Deposita, 38, 695-714. http://dx.doi.org/10.1007/s00126-003-0360-5

[35] Sinaré, M. (2013) Métallogénie du gisement aurifère de yaho, ceinture birimienne de Houndé, Burkina Faso. Mémoire, Université du Québec à Chicoutimi, 285. 